\title{
THE USAGE OF ANATOMAGE AND PLASTINATION IN ANATOMY LEARNING: STUDENT PERCEPTIONS AND LEARNING OUTCOMES
}

\author{
Nurfitri Bustamam ${ }^{1 *}$, Diana Agustini Purwaningastuti ${ }^{1}$ \\ ${ }^{1}$ Faculty of Medicine, Universitas Pembangunan Nasional Veteran Jakarta, Jakarta - INDONESIA \\ Submitted: 16 Nov 2018; Final Revision from Authors: 12 Apr 2021; Accepted: 12 Apr 2021
}

\begin{abstract}
Background: In the Academic Year 2017/2018 the Faculty of Medicine Universitas Pembangunan Nasional Veteran Jakarta (FMUPNVJ) began using anatomage and plastination as learning tools. This study aims to describe the learning process, compare learning outcomes of students after using anatomage and plastination with the learning outcomes of students in the previous academic year, and describe students' perceptions regarding the learning tools used.

Methods: A cross-sectional study was conducted on the population of second-semester FMUPNVJ students who had taken dermatomusculoskeletal (DMS) block in the academic year 2017/2018. Data were taken from the total population $(n=$ 163). A questionnaire with a 5-point Likert scale and open-ended questions were used to obtain student perceptions related to the learning process and the learning tools used. Semester grade point average (GPA) before taking the DMS block and results of anatomy practical exam of the subjects $(n=163)$ and students of the previous academic year $(n=157)$ were analyzed.
\end{abstract}

Results: The students appreciate learning using anatomage and plastination. The Mann-Whitney test result showed that there was no difference in semester GPA before taking DMS block between the two groups $(p=0.090)$. However, the learning outcomes after using anatomage and plastination were lower than those using only cadaver and mannequin ( $p=$ 0.002). Each learning tool has some advantages and disadvantages.

Conclusion: The usage of anatomage and plastination at Anatomy Laboratory FMUPNVJ has not been able to improve learning outcomes. Anatomage features need to be used optimally to enhance the learning outcomes.

Keywords: anatomage, anatomy learning, learning outcomes, plastination

\begin{abstract}
ABSTRAK
Latar belakang: Pada Tahun Akademik 2017/2018 Fakultas Kedokteran Universitas Pembangunan Nasional Veteran Jakarta (FKUPNVJ) mulai menggunakan anatomage dan plastisin sebagai alat pembelajaran. Penelitian ini bertujuan untuk mendeskripsikan proses pembelajaran menggunakan alat pembelajaran tersebut, membandingkan capaian pembelajaran mahasiswa setelah menggunakan anatomage dan plastisin dengan capaian pembelajaran mahasiswa tahun akademik sebelumnya, serta mendeskripsikan persepsi mahasiswa berkaitan dengan alat pembelajaran yang digunakan.
\end{abstract}

Metode: Penelitian potong lintang dilakukan pada populasi mahasiswa semester dua FKUPNVJ yang telah mengikuti blok dermatomusculoskeletal (DMS) pada Tahun Akademik 2017/2018. Data diambil dari total

*corresponding author, contact: nurfitri.bustamam@upnvj.ac.id 
populasi $(\mathrm{n}=163)$. Kuesioner dengan 5 skala Likert dan pertanyaan terbuka digunakan untuk mendapatkan persepsi mahasiswa berkaitan dengan proses pembelajaran dan berbagai alat pembelajaran yang digunakan. Indeks prestasi semester (IPS) sebelum mengikuti blok DMS serta hasil ujian praktikum anatomi dari subjek penelitian $(n=163)$ dan mahasiswa tahun akademik sebelumnya $(n=157)$ dianalisis.

Hasil: Mahasiswa mengapresiasi pembelajaran menggunakan anatomage dan plastisin. Hasil uji MannWhitney menunjukkan tidak ada perbedaan IPS pada kedua kelompok sebelum mengikuti blok DMS ( $\mathrm{p}$ $=0,090$ ). Namun, capaian pembelajaran dengan tambahan alat pembelajaran anatomage dan plastisin lebih rendah dibandingkan dengan capaian pembelajaran yang hanya dengan cadaver dan manikin $(p=0,002)$. Setiap alat pembelajaran mempunyai sejumlah kelebihan dan kekurangan.

Kesimpulan: Penggunaan anatomage dan plastisin di Laboratorium Anatomi FKUPNVJ belum dapat meningkatkan capaian pembelajaran. Fitur anatomage perlu digunakan secara optimal untuk meningkatkan capaian pembelajaran.

Kata kunci: anatomage, capaian pembelajaran, pembelajaran anatomi, plastisin

\section{PRACTICE POINTS}

- Penggunaan anatomage dan plastisin dalam praktikum anatomi diapresiasi oleh mahasiswa.

- Anatomage dan plastisin tidak dapat menggantikan cadaver.

- Sejumlah fitur pada anatomage dapat dimanfaatkan untuk memfasilitasi pembelajaran.

\section{PENDAHULUAN}

Anatomi merupakan ilmu dasar untuk memahami proses yang berkaitan dengan perubahan fisiologis dan patologis. ${ }^{1}$ Pengetahuan anatomi sangat penting bagi seorang dokter sebab merupakan dasar untuk melakukan pemeriksaan fisis, mengevaluasi gambaran radiologis atau hasil pencitraan, melakukan tindakan emergensi, dan berbagai prosedur termasuk melakukan tindakan bedah. ${ }^{2}$

Pembelajaran anatomi mengharuskan kemampuan untuk mengidentifikasi dan memahami berbagai struktur dalam bentuk tiga dimensi (3D) serta kaitan spasial terhadap struktur di sekitarnya. Dasar pengetahuan berbagai struktur anatomi umumnya diberikan melalui kuliah dengan gambar dua dimensi (2D) baik dari atlas maupun buku teks. Ilustrasi 2D statis tersebut terbatas untuk dapat mengekspos struktur 3D dinamis. Mahasiswa akan sulit memvisualisasikan gambar 2D sebagai 3D dan memahami aspek dinamis dari anatomi fungsional jika hanya menggunakan atlas dan buku teks anatomi. Oleh karena itu, perlu diberikan praktikum anatomi menggunakan cadaver yang dapat dirotasi dan dimanipulasi dari berbagai sisi untuk mengidentifikasi suatu struktur. Melalui praktikum anatomi, diharapkan pemahaman mahasiswa dalam struktur 3D akan meningkat. ${ }^{3,4}$

Selama berabad-abad digunakan cadaver untuk mengetahui bentuk, ukuran, tekstur, orientasi spasial, dan variasi anatomi. ${ }^{5}$ Namun, cadaver sudah mulai ditinggalkan dalam praktikum anatomi. Hal tersebut antara lain disebabkan oleh keterbatasan donor organ, jumlah mahasiswa yang semakin banyak, keterbatasan jumlah pakar anatomi, perubahan kurikulum yang mengurangi alokasi waktu untuk pembelajaran anatomi, dan masalah etik. ${ }^{2,6}$ Beberapa institusi pendidikan telah menggunakan alat pembelajaran inovatif berupa anatomage table (anatomage) dan plastination (plastisin) untuk menggantikan cadaver. ${ }^{2}$ 
Pada Tahun Akademik (TA) 2017/2018 di Fakultas Kedokteran Universitas Pembangunan Nasional Veteran Jakarta (FKUPNVJ) mulai digunakan anatomage dan plastisin dalam pembelajaran praktikum anatomi blok dermatomusculoskeletal (DMS) sebagai tambahan alat pembelajaran selain cadaver dan manekin. Anatomage adalah diseksi virtual yang direkonstruksi dari cadaver. Menggunakan anatomage, mahasiswa dapat memvisualisasikan struktur anatomi dari berbagai planus, melakukan diseksi, melakukan rekonstruksi, mengisolasi suatu struktur, melakukan zoom in and out, melihat bentuk dan kaitannya dengan struktur lain, serta menguji pemahaman menggunakan quiz. ${ }^{7,8}$ Mahasiswa juga dapat melakukan insisi dan membuka jaringan secara bertahap untuk melihat bagian dalam dari suatu struktur. ${ }^{9}$ Plastisin adalah tubuh manusia yang diawetkan menggunakan sejenis plastik. Dibandingkan dengan cadaver, plastisin lebih awet dan tidak berbau, tetapi fragile dan tidak fleksibel sehingga interaksi belajar dengan menyentuh spesimen ini lebih dibatasi. ${ }^{2}$ Penggunaan anatomage dan plastisin dalam praktikum anatomi di FKUPNVJ diharapkan dapat meningkatkan capaian pembelajaran.

Capaian pembelajaran ditentukan oleh proses pembelajaran. Ada sejumlah faktor yang menentukan proses pembelajaran, yaitu: karakteristik mahasiswa (gaya belajar, pengetahuan/pengalaman sebelumnya), kurikulum (materi dan alokasi waktu), metode pengajaran, dan alat pembelajaran. ${ }^{10}$ Berdasarkan teori tersebut, penggunaan anatomage dan plastisin dalam praktikum anatomi di FKUPNVJ akan mempengaruhi proses pembelajaran dan menentukan capaian pembelajaran. Gambaran proses pembelajaran terkait dengan penggunaan alat pembelajaran tersebut penting diketahui khususnya berdasarkan persepsi mahasiswa. Persepsi mahasiswa tersebut merupakan masukan untuk perbaikan sejumlah faktor yang menentukan proses pembelajaran, misalnya metode pembelajaran dan kurikulum (materi dan alokasi waktu).

Berdasarkan rasional tersebut, penelitian ini dilakukan dengan tujuan: 1) mendeskripsikan pembelajaran praktikum anatomi di FKUPNVJ dengan tambahan alat pembelajaran berupa anatomage dan plastisin, 2) membandingkan capaian pembelajaran praktikum anatomi setelah menggunakan anatomage dan plastisin sebagai alat pembelajaran tambahan dengan capaian pembelajaran pada mahasiswa tahun akademik sebelumnya yang hanya menggunakan cadaver dan manikin, dan 3) mendeskripsikan persepsi mahasiswa berkaitan dengan penggunaan berbagai alat pembelajaran dalam praktikum anatomi.

\section{METODE}

\section{Kelaikan etik}

Penelitian ini dilaksanakan pada bulan September 2018 setelah mendapat persetujuan etik (ethical approval) dari Komisi Etik Penelitian Universitas Pembangunan Nasional Veteran Jakarta (Surat Nomor: B/1605/IX/2018/KEPK).

\section{Instrumen}

Pada penelitian digunakan kuesioner dengan 5 skala Likert untuk mendapatkan persepsi subjek berkaitan dengan pembelajaran praktikum anatomi mencakup proses pembelajaran, alat pembelajaran, pemahaman subjek terhadap materi, dan keyakinan subjek terhadap capaian pembelajaran tersebut. Pada penelitian juga digunakan pertanyaan terbuka untuk menjaring persepsi subjek berkaitan dengan penggunaan anatomage, plastisin, cadaver, dan manikin dalam praktikum anatomi.

\section{Desain, populasi, dan subjek penelitian}

Penelitian menggunakan desain potong lintang (cross sectional) pada populasi mahasiswa FKUPNVJ semester dua yang telah mengikuti pembelajaran praktikum blok DMS TA 2017/2018. Kriteria inklusi subjek penelitian adalah mahasiswa yang pertama kali mengikuti praktikum anatomi blok DMS dan mempunyai pengalaman belajar menggunakan anatomage dan plastisin serta bersedia menjadi subjek penelitian. Mahasiswa yang mengulang praktikum anatomi blok DMS dieksklusi dari penelitian. Pada penelitian ini ditetapkan untuk mengambil data dari total populasi yang berjumlah 163 orang. 


\section{Prosedur penelitian}

Prosedur pengambilan data diawali dengan menjelaskan kepada populasi penelitian di dalam kelas tentang rasional dan tujuan penelitian, makna/pengertian dari setiap butir kuesioner serta jaminan kerahasiaan data yang dikumpulkan. Subjek penelitian diberi kesempatan untuk bertanya dan diharapkan mendapat penjelasan yang cukup terkait dengan penelitian. Selanjutnya peneliti menitipkan kuesioner kepada ketua kelas untuk dibagikan kepada subjek. Ketua kelas diminta mengumpulkan kembali kuesioner yang telah diisi kepada peneliti keesokan harinya. Pada penelitian diambil pula data indeks prestasi semester (IPS) sebelum mengikuti blok DMS dan hasil objective structured practical examination (OSPE) anatomi dari subjek penelitian (n $=163$ ) dan mahasiswa tahun akademik sebelumnya ( $\mathrm{n}=157)$ yang mengikuti blok yang sama. Capaian pembelajaran dianalisis berdasarkan hasil OSPE.

\section{Analisis data}

Data yang didapatkan dianalisis menggunakan komputer dan disajikan dalam bentuk tabel. Data IPS dan capaian pembelajaran praktikum anatomi pada kedua kelompok (subjek penelitian dan mahasiswa tahun akademik sebelumnya) dibandingkan menggunakan uji Mann-Whitney. Uji statistik dianggap bermakna bila $\mathrm{p}<0,05$.

\section{HASIL DAN PEMBAHASAN}

\section{Pembelajaran praktikum anatomi di FKUPNVJ}

Setiap sesi praktikum anatomi diikuti oleh 20-25 mahasiswa. Praktikum diawali dengan penjelasan singkat tentang tujuan dan materi pembelajaran oleh dosen menggunakan power point text. Selanjutnya mahasiswa kembali mendapat penjelasan dari dosen menggunakan anatomage selama 30 menit. Setelah mendapat penjelasan menggunakan anatomage, mahasiswa dibagi menjadi beberapa kelompok kecil (5-6 orang) yang dibimbing oleh empat orang asisten dosen pada setiap sesi praktikum. Alat pembelajaran yang digunakan dalam kelompok kecil adalah plastisin, cadaver, dan manikin (Gambar 1).
Agar memudahkan mengikuti praktikum, setiap mahasiswa mendapatkan daftar tilik (checklist) dari struktur anatomi yang harus dipelajari. Mahasiswa juga diminta untuk menggunakan atlas anatomi sebagai rujukan pada saat praktikum. Pada setiap sesi praktikum mahasiswa diberi kesempatan bertanya kepada dosen/asisten dosen. Praktikum anatomi berlangsung total selama 2,5 jam.

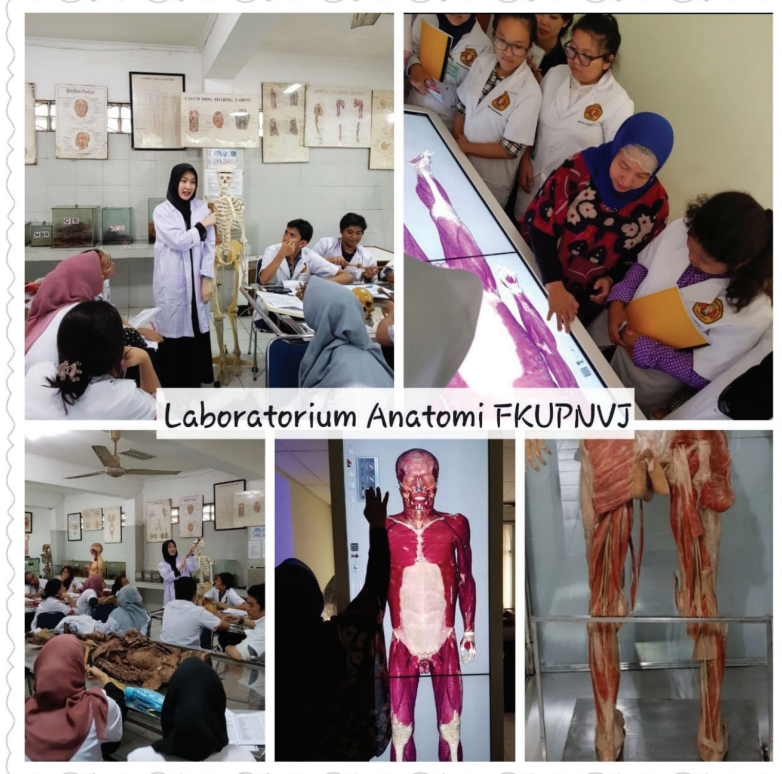

Gambar 1. Pembelajaran Praktikum Anatomi di FKUPNVJ

Sebagian besar (73\%) subjek penelitian ini adalah perempuan dengan median usia 19 (17-19) tahun. Pada Tabel 1 dapat dilihat sebanyak 44,5\% mahasiswa persepsinya netral terkait pernyataan bahwa metode pembelajaran yang digunakan sudah memuaskan untuk mempelajari anatomi blok DMS dan hanya $34,4 \%$ mahasiswa yang menyatakan setuju atau sangat setuju. Sebagian besar mahasiswa menyatakan setuju atau sangat setuju bahwa pembelajaran anatomi di FKUPNVJ memberikan dasar yang kuat dan bekal yang cukup untuk pembelajaran tahap profesi serta melakukan tugasnya kelak sebagai seorang dokter, misalnya melakukan pemeriksaan fisis, membaca hasil pencitraan, dan melakukan berbagai prosedur termasuk tindakan bedah. 
Tabel 1. Persepsi Mahasiswa tentang Pembelajaran Praktikum Anatomi ( $=163)$

\begin{tabular}{|c|c|c|c|c|c|c|}
\hline No. & Pernyataan & $\begin{array}{l}\text { STS } \\
(\%)\end{array}$ & $\begin{array}{l}\text { TS } \\
(\%)\end{array}$ & $\begin{array}{l}\mathrm{N} \\
(\%)\end{array}$ & $\begin{array}{l}S \\
(\%)\end{array}$ & $\begin{array}{l}\text { SS } \\
(\%)\end{array}$ \\
\hline 1. & Anatomage meningkatkan minat saya belajar anatomi & 0 & 1,7 & 25,8 & 50,8 & 21,7 \\
\hline 2. & Saya senang belajar menggunakan anatomage & 0 & 3,3 & 21,7 & 44,2 & 30,8 \\
\hline 3. & $\begin{array}{l}\text { Anatomage meningkatkan kemampuan saya untuk } \\
\text { memvisualisasikan struktur dalam tiga dimensi }\end{array}$ & 0 & 5,5 & 19,2 & 46,7 & 29,2 \\
\hline 4. & $\begin{array}{l}\text { Anatomage membantu saya memvisualisasikan hubungan suatu } \\
\text { struktur dengan struktur lainnya }\end{array}$ & 0 & 4,2 & 27,5 & 48,3 & 20,0 \\
\hline 5. & $\begin{array}{l}\text { Saya lebih dapat berpartisipasi dalam praktikum anatomi dengan } \\
\text { adanya anatomage }\end{array}$ & 1,7 & 13,3 & 50,0 & 22,5 & 12,5 \\
\hline 6. & Anatomage membuat pembelajaran anatomi menjadi efektif & 0,8 & 10,0 & 37,5 & 35,8 & 15,8 \\
\hline 7. & $\begin{array}{l}\text { Pembelajaran anatomi menjadi lebih interaktif dengan } \\
\text { menggunakan anatomage }\end{array}$ & 0 & 15,1 & 29,4 & 37,8 & 17,6 \\
\hline 8. & Pembelajaran menggunakan anatomage harus ditambah waktunya & 0 & 5,0 & 24,2 & 20,8 & 50,0 \\
\hline 9. & $\begin{array}{l}\text { Anatomage lebih baik daripada cadaver untuk mempelajari } \\
\text { anatomi }\end{array}$ & 9,2 & 28,6 & 22,7 & 30,3 & 9,2 \\
\hline 10. & $\begin{array}{l}\text { Anatomage dapat menggantikan cadaver dalam pembelajaran } \\
\text { anatomi }\end{array}$ & 22,5 & 35,8 & 25,8 & 11,7 & 4,2 \\
\hline 11. & Cadaver harus tetap ada dalam praktikum anatomi & 0 & 1,7 & 4,2 & 22,5 & 71,7 \\
\hline 12. & $\begin{array}{l}\text { Cadaver penting untuk menunjukkan variabilitas struktur } \\
\text { anatomi }\end{array}$ & 0 & 0 & 7,5 & 28,3 & 64,2 \\
\hline 13. & $\begin{array}{l}\text { Plastisin membantu saya memahami anatomi } \\
\text { dermatomusculoskeletal }\end{array}$ & 0 & 0,8 & 7,5 & 43,3 & 48,3 \\
\hline 14. & $\begin{array}{l}\text { Saya sulit memvisualisasikan struktur 3D suatu organ dengan } \\
\text { plastisin sebab hanya dapat dilihat, tetapi tidak boleh dipegang }\end{array}$ & 0 & 20,8 & 34,2 & 33,3 & 11,7 \\
\hline 15. & $\begin{array}{l}\text { Metode pembelajaran praktikum anatomi blok DMS sudah } \\
\text { memuaskan }\end{array}$ & 5,0 & 16,0 & 44,5 & 31,9 & 2,5 \\
\hline 16. & $\begin{array}{l}\text { Saya yakin nilai ujian anatomi saya lebih baik dengan tambahan } \\
\text { alat pembelajaran berupa anatomage dan plastisin }\end{array}$ & 0 & 5,8 & 27,5 & 45,8 & 20,8 \\
\hline 17. & $\begin{array}{l}\text { Saya yakin pembelajaran anatomi di FKUPNVJ memberikan } \\
\text { dasar yang kuat dan bekal yang cukup untuk pembelajaran tahap } \\
\text { profesi }\end{array}$ & 0,8 & 9,2 & 22,5 & 45,0 & 22,5 \\
\hline 18. & $\begin{array}{l}\text { Saya yakin pembelajaran anatomi di FKUPNVJ memberikan } \\
\text { dasar yang kuat untuk melakukan tugas seorang dokter, misalnya } \\
\text { melakukan pemeriksaan fisis, membaca hasil pencitraan, dan } \\
\text { melakukan berbagai prosedur termasuk tindakan bedah. }\end{array}$ & 0,8 & 8,3 & 22,5 & 36,7 & 31,7 \\
\hline
\end{tabular}

Keterangan: sangat tidak setuju (STS), tidak setuju (TS), netral (N), setuju (S), sangat setuju (SS)

\section{Capaian pembelajaran}

Hasil penelitian menunjukkan mahasiswa kedokteran yang mendapatkan nilai baik dalam hal pengetahuan anatomi menggunakan strategi belajar mengingat dengan cara memahami (deep learning) dan melakukan visualisasi. ${ }^{11}$ Oleh karenanya pembelajaran anatomi perlu menggunakan alat pembelajaran (learning tool) untuk membantu visualisasi. FKUPNVJ menggunakan anatomage dan plastisin sebagai tambahan alat pembelajaran 
untuk membantu mahasiswa memvisualisasikan struktur anatomi, sehingga diharapkan dapat meningkatkan capaian pembelajaran. Pada penelitian ini didapatkan sebanyak 45,8\% subjek setuju dan 20,8\% subjek sangat setuju terhadap pernyataan bahwa nilai ujian anatominya akan lebih baik dengan tambahan alat pembelajaran berupa anatomage dan plastisin (Tabel 1).

Pada penelitian ini ingin diketahui capaian pembelajaran praktikum anatomi setelah menggunakan anatomage dan plastisin sebagai alat pembelajaran tambahan dibandingkan dengan capaian pembelajaran pada mahasiswa tahun akademik sebelumnya yang hanya menggunakan cadaver dan manikin. Kedua kelompok tersebut tidak berbeda berdasarkan usia dan jenis kelamin (Tabel 2).
Tabel 2. Karakteristik Demografi Mahasiswa Yang Mengikuti Praktikum DMS

\begin{tabular}{lccc} 
& \multicolumn{2}{c}{ Mahasiswa } & \\
\cline { 2 - 3 } Variabel & $\begin{array}{c}\text { TA 2016/2017 } \\
(\mathbf{N}=157)\end{array}$ & $\begin{array}{c}\text { TA 2017/2018 } \\
(\mathbf{N}=163)\end{array}$ & \\
& & & \\
Seks & & & \\
$\quad$ Perempuan & $119(75,8 \%)$ & $119(73 \%)$ & 0,664 \\
Laki-laki & $38(24,2 \%)$ & $44(27 \%)$ & \\
Usia & $19(17-19)$ & $19(17-19)$ & 0,568 \\
\hline
\end{tabular}

Hasil uji Mann-Whitney juga menunjukkan bahwa IPS sebelum mengikuti praktikum anatomi blok DMS pada kedua kelompok mahasiswa tersebut tidak berbeda $(p=0,090)$ (Tabel 3). Hal tersebut menunjukkan bahwa kemampuan akademik pada kedua kelompok mahasiswa tersebut sama.

Tabel 3. Indeks Prestasi Semester Mahasiswa Sebelum Mengikuti Praktikum Anatomi Blok DMS

\begin{tabular}{cccccc} 
Mahasiswa & $\mathbf{N}$ & Median & Minimum & Maksimum & $\mathbf{p}$ \\
TA 2016/2017 & 157 & 3,38 & 1,55 & 3,88 & 0,090 \\
TA 2017/2018 & 163 & 3,31 & 1,81 & 3,75 & \\
\hline
\end{tabular}

Setelah mengikuti praktikum anatomi blok belajar menggunakan cadaver dan manikin. Hasil DMS didapatkan hasil OSPE anatomi blok DMS uji Mann-Whitney menunjukkan kedua capaian mahasiswa yang menggunakan tambahan alat pembelajaran tersebut berbeda signifikan $(p=0,002)$ pembelajaran berupa anatomage dan plastisin lebih (Tabel 4). rendah dibandingkan dengan mahasiswa yang hanya

Tabel 4. Hasil OSPE Anatomi Blok DMS

\begin{tabular}{lccccc}
\multicolumn{1}{c}{ Alat Pembelajaran } & N & Median & Minimum & Maksimum & p \\
Cadaver + Manikin & 157 & 65 & 20 & 95 & 0,002 \\
Tambahan Alat Pembelajaran & 163 & 60 & 20 & 85 & \\
(Anatomage + Plastisin) & & & & & \\
\hline
\end{tabular}

Sejumlah penelitian yang bertujuan untuk mengetahui capaian pembelajaran praktikum anatomi menggunakan anatomage menunjukkan hasil yang beragam. Hasil penelitian menunjukkan bahwa konjugasi anatomage dan cadaver dapat meningkatkan nilai ujian praktikum anatomi. ${ }^{4}$ Hasil serupa didapatkan pada penelitian yang menunjukkan bahwa mahasiswa kedokteran yang belajar menggunakan cadaver dan anatomage nilai quiz anatominya tiga kali lebih baik dibandingkan dengan kelompok yang belajar dengan cadaver dan buku anatomi topografi. ${ }^{12}$ Penelitian lain yang membandingkan pembelajaran anatomi menggunakan anatomage dan cadaver menunjukkan bahwa nilai quiz anatomi musculoskeletal lebih baik pada kelompok yang menggunakan anatomage 
dibandingkan kelompok yang menggunakan cadaver. Namun, nilai quiz anatomi pelvis/perineum pada kedua kelompok tersebut tidak berbeda secara signifikan. Berdasarkan hasil penelitian tersebut disimpulkan bahwa pembelajaran beberapa regio anatomi tidak bergantung pada modalitas yang digunakan. ${ }^{13}$

Sesungguhnya ada sejumlah fitur anatomage yang dapat digunakan untuk memfasilitasi pembelajaran, antara lain: berbagai tipe quiz, layout struktur anatomi dalam bentuk 2D, 3D dan histologinya, serta case library yang menyimpan koleksi hasil CT scan/MRI. ${ }^{14}$ Hasil penelitian menunjukkan bahwa pembelajaran menggunakan anatomage disertai hasil radiologi (CT scan) secara signifikan meningkatkan skor nilai anatomi. Subjek dapat mengenali struktur anatomi pada data pencitraan sehingga meningkatkan motivasi belajar dan pemahaman. ${ }^{15}$

Sebaliknya, hasil penelitian pada mahasiswa kedokteran tahun pertama di Gujarat menunjukkan tidak ada perbedaan pengetahuan neuroanatomi antara kelompok yang belajar dengan anatomage dibandingkan kelompok yang belajar dengan diseksi cadaver. ${ }^{8}$ Hasil literature review terhadap 30 penelitian yang menggunakan model 3D digital dan dampaknya terhadap pembelajaran anatomi juga tidak menunjukkan bukti yang cukup kuat bahwa model 3D digital lebih unggul daripada model pembelajaran tradisional (cadaver). ${ }^{3}$

Ada sejumlah faktor yang mempengaruhi capaian pembelajaran menggunakan model 3D digital, yaitu: 1) desain software, 2) kemampuan spasial, cognitive load, degree of learner control, dan prior knowledge (karakteristik mahasiswa), dan 3) kurikulum yang mencakup alokasi waktu penggunaan alat, ketersediaan staf pengajar untuk memberikan umpan balik pada mahasiswa, regio anatomi yang dipelajari, tahapan kurikulum, dan jumlah mahasiswa. ${ }^{3,16}$

Pada praktikum anatomi DMS di FKUPNVJ yang mengoperasikan anatomage adalah dosen. Jika anatomage dioperasikan oleh dosen, ada kemungkinan mahasiswa tidak dapat mengintegrasikan informasi yang dilihatnya dengan informasi sebelumnya. Apalagi jika alokasi waktu yang tersedia kurang. Capaian pembelajaran akan lebih baik jika mahasiswa diberikan kesempatan untuk mengoperasikan sendiri. ${ }^{16}$ Sebaliknya dalam praktikum menggunakan cadaver dan manikin, subjek penelitian ini dapat melihat atau mengkaji informasi dalam jangka waktu yang lebih lama hingga informasi tersebut dapat dipahami. Diduga hal inilah yang menjadi salah satu penyebab capaian pembelajaran dengan tambahan alat anatomage dan plastisin lebih rendah daripada pembelajaran yang hanya mengunakan cadaver dan manikin.

Pada penelitian ini didapatkan pula hanya sebagian kecil mahasiswa yang setuju atau sangat setuju bahwa anatomage dapat meningkatkan partisipasi dalam pembelajaran serta membuat pembelajaran lebih efektif dan interaktif (Tabel 1). Sejumlah saran mahasiswa untuk memfasilitasi pembelajaran menggunakan anatomage antara lain: "Penggunaan anatomage sebaiknya bergiliran dalam kelompok kecil", "Anatomage akan lebih bermanfaat jika dapat dioperasikan sendiri", "Beri kesempatan mahasiswa untuk mengoperasikan anatomage" dan "Alokasi waktu pembelajaran menggunakan anatomage agar ditambah.”

Pendapat lain menyebutkan bahwa model 3D nondigital lebih menjanjikan sebagai alat pembelajaran daripada model 3D digital untuk memahami struktur anatomi. Pada saat model non-digital disentuh dan digerakan akan memberikan interaksi yang lebih melalui multiple somato-sensory inputs (visual, tekstur, dan berat). Selanjutnya berbagai asupan sensorik tersebut akan diintegrasikan di otak untuk meningkatkan persepsi stereoskopik dari suatu objek. ${ }^{2}$ Sebaliknya anatomage sebagai model 3D digital hanya memberikan informasi visual untuk pemahaman stereoskopik. Pendapat ini sesuai dengan hasil penelitian yang menunjukkan bahwa mahasiswa agak sulit membayangkan struktur anatomi tanpa menyentuhnya (Tabel 5).

Penelitian yang mempelajari mekanisme superioritas model fisik 3D dibandingkan dengan presentasi komputer dalam pembelajaran anatomi menunjukkan bahwa hasil pembelajaran lebih baik pada kelompok subjek yang menggunakan model fisik 3D daripada menggunakan presentasi komputer meskipun subjek tidak dapat menyentuh model fisik tersebut. Hasil pembelajaran menggunakan model 
fisik 3D menjadi tidak lebih baik dibandingkan dengan pembelajaran menggunakan presentasi komputer jika salah satu mata subjek ditutup. Disimpulkan bahwa keunggulan penggunaan model fisik 3D dalam pembelajaran anatomi ditentukan oleh stereoscopic vision bukan oleh asupan taktil (haptic feedback). ${ }^{17}$

\section{Alat Pembelajaran Anatomi}

Hasil penelitian ini menunjukkan bahwa alat pembelajaran yang paling dapat memfasilitasi subjek untuk memahami anatomi pada blok DMS beragam. Yang paling banyak dipilih oleh subjek berturutturut adalah plastisin, anatomage, cadaver, dan manikin. Hasil berbeda didapatkan pada penelitian cohort untuk mengetahui alat pembelajaran yang paling dipilih mahasisiwa dalam praktikum anatomi pada tahun $2013(\mathrm{n}=333)$ dan tahun $2014(\mathrm{n}=$ 329). Pada penelitian tahun 2014 didapatkan yang paling dipilih mahasiswa berturut-turut adalah video/animasi $(77,8 \%)$, manikin $(63,9 \%)$, plastisin $(58,4 \%)$, dan anatomage $(42,4 \%)$. Hasil penelitian tersebut juga menunjukkan bahwa persentase mahasiswa yang memilih anatomage meningkat dari 36,9\% pada tahun 2013 menjadi 42,4\% pada tahun $2014(p=0,022)$. Peningkatan persentase tersebut disebabkan staf pengajar baru pertama kali (belum familiar) menggunakan anatomage pada tahun 2013. Selanjutnya pada tahun 2014, staf pengajar telah lebih berpengalaman dan lebih percaya diri memfasilitasi pembelajaran mahasiswa menggunakan anatomage. ${ }^{18}$

Persepsi mahasiswa berkaitan dengan kelebihan (+) dan kekurangan (-) alat pembelajaran yang digunakan dalam praktikum anatomi blok DMS di FKUPNVJ dapat dilihat pada Tabel 5.

Tabel 5. Persepsi Mahasiswa tentang Alat Pembelajaran Praktikum Anatomi

\begin{tabular}{|c|c|c|}
\hline No. & Alat Pembelajaran & Persepsi Mahasiswa \\
\hline \multirow[t]{2}{*}{1.} & \multirow[t]{2}{*}{ Plastisin } & $\begin{array}{l}\text { - Lebih detail dan jelas strukturnya } \\
\text { - Bentuknya sesuai dengan yang ada di atlas anatomi } \\
\text { - Memudahkan mengingat bentuk } \\
\text { - Batas antar otot dan bagian lainnya jelas terlihat } \\
\text { - Plastisin sesuai dengan bentuk tubuh manusia, sehingga dapat } \\
\text { menyiapkan mahasiswa menghadapi pasien }\end{array}$ \\
\hline & & $\begin{array}{l}\text { - Hanya dapat dilihat dari beberapa sisi saja } \\
\text { - Sulit diingat struktur/anatominya tanpa disentuh }\end{array}$ \\
\hline \multirow[b]{2}{*}{2.} & \multirow[b]{2}{*}{ Anatomage } & $\begin{array}{l}\text { - Dapat dilihat dari lapisan luar hingga terdalam } \\
\text { - Membantu melihat struktur 3D yang tidak dapat dilihat dengan } \\
\text { cadaver } \\
\text { - Dapat melihat hubungan suatu struktur dengan struktur lainnya } \\
\text { - Lebih baik dari plastisin, serasa membedah sendiri } \\
\text { - Lebih menarik } \\
\text { - Praktis untuk mengasah hapalan karena ada quiz }\end{array}$ \\
\hline & & $\begin{array}{l}\text { - Agak sulit diingat/dibayangkan karena tidak dapat disentuh } \\
\text { - Terlihat lebih modern dan efektif, namun waktu penggunaannya } \\
\text { terlalu cepat } \\
\text { - Pembelajaran menjadi kurang kondusif karena terlalu banyak } \\
\text { mahasiswa } \\
\text { - Anatomage kurang bermanfaat jika tidak dioperasikan sendiri } \\
\text { - Akan bermanfaat jika pembelajaran menggunakan anatomage dapat } \\
\text { pula diakses pada saat self study }\end{array}$ \\
\hline
\end{tabular}




\section{No. Alat Pembelajaran}

3. Cadaver

\section{Persepsi Mahasiswa}

- Lebih real dan dapat dirasakan strukturnya

- Dapat dilihat, dipegang dan dirasakan langsung

- Dapat langsung divisualisasikan dan dipegang, tetapi cadavernya kurang bagus

$+\quad$ Memiliki pengalaman langsung memegang tubuh manusia

- Dapat melihat variasi anatomi tubuh manusia

- Sangat penting untuk melihat struktur anatomi sesungguhnya

- Lebih mudah diingat

Sukar membedakan organnya jika cadaver telah rusak

- Membantu memahami struktur secara garis besar/general

- Gambaran jelas karena dibantu warna tertentu

- Serupa dengan yang ada di buku ajar, lebih mudah diingat

- Gambaran sesuai aslinya dan dapat dipengang sehingga mudah diingat

4. Manikin

\section{Plastisin}

Plastisin adalah alat pembelajaran yang paling dipilih subjek dalam praktikum anatomi blok DMS. Hampir seluruh subjek (91,6\%) setuju dan sangat setuju bahwa plastisin membantu memahami anatomi blok DMS. Hal tersebut karena struktur anatomi pada plastisin jelas terlihat seperti di atlas anatomi (Tabel 5). Namun, mahasiswa dibatasi untuk menyentuh plastisin karena strukturnya relatif lebih fragile. Akibatnya mahasiswa hanya dapat melihat struktur anatomi dari satu sisi saja sehingga visualisasi untuk memahami struktur 3D menjadi terbatas. Kelemahan tersebut dapat diatasi dengan menggunakan alat pembelajaran lainnya misalnya manikin atau cadaver. Sesungguhnya terdapat sejumlah keterbatasan plastisin, yaitu mengalami penyusutan, kehilangan tekstur, warna natural, dan detail jaringan. ${ }^{19}$

\section{Anatomage}

Sebanyak 72,5\% dan 75,9\% subjek berturut-turut setuju atau sangat setuju bahwa belajar dengan anatomage menyenangkan dan dapat meningkatkan minat belajar. Mereka juga setuju atau sangat setuju bahwa anatomage dapat meningkatkan pemahaman anatomi untuk melihat struktur tiga dimensi dan membantu memvisualisasikan hubungan suatu struktur dengan struktur lainnya (Tabel 1). Hasil serupa didapatkan pada penelitian dengan subjek mahasiswa kedokteran tahun pertama di Gujarat yang menunjukkan 51\% dari 122 subjek berpendapat bahwa anatomage membantu belajar anatomi lebih baik, $79 \%$ subjek menyatakan anatomage meningkatkan minat dan pengalaman belajar anatomi, dan $75 \%$ setuju bahwa penggunaan anatomage menghemat waktu pembelajaran untuk memahami suatu struktur. ${ }^{8}$

Hasil survei pada 17 mahasiswa Post-Primary Imaging Science Program, University of Nebraska Medical Center yang secara intensif menggunakan anatomage di kelas juga menunjukkan bahwa sebagian besar mahasiswa setuju bahwa penggunaan anatomage bermanfaat untuk pembelajaran. ${ }^{7}$ Hasil serupa didapatkan dari survei di University of Gondar, Ethiopia pada mahasiswa kedokteran tahun kedua yang menunjukkan sebanyak 80,89\% subjek setuju bahwa anatomage merupakan alat pembelajaran tambahan yang bermanfaat dalam pembelajaran. ${ }^{20}$

Mahasiswa menyukai anatomage karena struktur yang dipelajari dapat dirotasi, dimanipulasi, dan dilakukan diseksi virtual untuk meningkatkan pemahaman topografi. Adanya tombol "reset" memungkinkan mahasiswa untuk mengulang kembali proses diseksi virtual beberapa kali. Anatomage membantu mahasiswa mengingat berbagai struktur anatomi lebih baik. Penelitian lain menunjukkan bahwa hal yang paling bermanfaat dari anatomage bagi mahasiswa adalah pemahaman ukuran organ dan kaitannya. 
Pengalaman belajar menggunakan anatomage akan lebih ditingkatkan melalui kesempatan mempelajari "material" sesungguhnya. ${ }^{9}$ Keterbatasan dari anatomage adalah hanya dapat dioperasikan oleh satu orang. ${ }^{18}$

\section{Cadaver}

Pada penelitian ini 94,5\% subjek menyatakan setuju dan sangat setuju bahwa cadaver harus tetap ada dalam praktikum anatomi dan 92,5\% setuju dan sangat setuju bahwa cadaver penting untuk menunjukkan variabilitas struktur anatomi (92,5\%). Pada penelitan ini hanya sebagian kecil (15,9\%) subjek yang berpendapat bahwa cadaver dapat digantikan dengan anatomage (Tabel 1). Subjek juga berpendapat bahwa dengan cadaver dapat dilihat struktur sesungguhnya dan memperoleh pengalaman memegang langsung tubuh manusia (Tabel 5).

Terdapat sejumlah keuntungan jika menggunakan cadaver, yaitu melatih keterampilan berkaitan dengan diseksi cadaver, memahami kaitan antara simptom dan patologi, membangun profesionalisme termasuk kerjasama kelompok, stress coping, melihat variasi dan detail, mengenal tekstur anatomi yang lebih serupa dengan kondisi hidup, dan membangun empati terhadap variasi anatomi. ${ }^{19}$ Hasil ini sejalan dengan pendapat 48 dokter bedah dari lima RS Pendidikan University College Cork, Ireland yang menyatakan bahwa cadaver adalah alat pembelajaran yang paling baik untuk mempelajari anatomi. ${ }^{6}$

\section{Manikin}

Pada penelitian ini didapatkan manikin merupakan alat pembelajaran yang paling sedikit dipilih oleh subjek untuk memahami anatomi blok DMS. Subjek berpendapat bahwa manikin dapat membantu memahami struktur secara garis besar dan jelas strukturnya karena dibantu warna tertentu, tetapi manikin berbeda dengan struktur sesungguhnya (Tabel 5). Sebaliknya, penelitian pada mahasiwa kedokteran di Pakistan menunjukkan bahwa hasil pembelajaran anatomi kepala leher lebih baik menggunakan model plastik (manikin) daripada diseksi cadaver. Hal tersebut diduga karena jumlah mahasiswa dalam kelompok yang mengikuti proses diseksi cadaver cukup banyak. Selain itu, anatomi regio yang dipelajari kompleks. ${ }^{21}$

Secara keseluruhan hasil penelitian ini menunjukkan alat pembelajaran yang paling bermanfaat bagi subjek dalam praktikum anatomi beragam. Setiap alat pembelajaran mempunyai sejumlah kelebihan dan kekurangan. Hasil serupa didapatkan dalam penelitian yang menunjukkan 25\% dari 304 mahasiswa MIMER Medical College India dapat memahami anatomi lebih baik dengan alat pembelajaran selain cadaver. Oleh karena itu, akan lebih baik digunakan berbagai alat pembelajaran dalam praktikum anatomi untuk memaksimalkan hasil pembelajaran. ${ }^{5}$

Berkaitan dengan pembelajaran anatomi blok DMS di FKUPNVJ, ada sejumlah hal yang dapat dicontoh dari institusi lainnya. Mahasiswa MIMER Medical College India menyarankan pembelajaran anatomi musculoskeletal perlu menggunakan living anatomy untuk memahami pergerakan otot dan sendi, serta mengetahui lokasi/bagian dari struktur superfisial otot dan sendi yang dapat dipalpasi. ${ }^{5}$ Selain itu, anatomi harus diajarkan dalam konteksnya sehingga tidak saja meningkatkan pengetahuan anatomi, tetapi juga meningkatkan aplikasinya dalam memecahkan masalah, misalnya dalam konteks pemeriksaan fisis atau pembelajaran radiologi (x-ray, CT scan, MRI). ${ }^{22}$ Penggunaan hasil pencitraan dalam pembelajaran anatomi penting dilakukan karena dokter hampir selalu menggunakan hasil pemeriksaan penunjang tersebut. $^{5}$

Kelebihan penelitian ini adalah mengidentifikasi persepsi mahasiswa dan capaian pembelajaran berkaitan dengan penggunaan anatomage dan plastisin yang masih belum banyak digunakan dalam pendidikan dokter tahap akademik di Indonesia.

Penelitian ini memiliki keterbatasan sebagai berikut: 1) kelompok pembanding adalah mahasiswa tahun akademik sebelumnya. Meskipun kemampuan akademik (IPS) pada kedua kelompok sebelum mengikuti blok DMS secara statistik tidak berbeda, tetapi lingkungan belajar juga berpengaruh terhadap capaian pembelajaran, dan 2) populasi penelitian ini terbatas hanya pada mahasiswa tahun pertama yang mempelajari dermatomusculoskeletal. Perlu dilakukan penelitian bagaimana hasilnya pada populasi 
mahasiswa tahun ke-2 atau ke-3 yang mempelajari sistem organ/regio anatomi yang berbeda.

\section{KESIMPULAN}

Pembelajaran praktikum anatomi di FKUPNVJ sudah berjalan cukup baik. Namun, tambahan alat pembelajaran berupa anatomage dan plastisin belum dapat meningkatkan capaian pembelajaran praktikum anatomi.

\section{SARAN}

Beberapa upaya yang dapat dilakukan untuk memaksimalkan capaian pembelajaran anatomi dengan anatomage adalah memanfaatkan secara optimal fitur yang tersedia, menggunakannya secara bergiliran dalam kelompok kecil, dan memberi kesempatan mahasiswa untuk mengoperasikannya sendiri. Perlu dilakukan penelitian tentang manfaat penggunaan sejumlah fitur anatomage terhadap capaian pembelajaran.

\section{DEKLARASI KEPENTINGAN}

Para penulis mendeklarasikan bahwa tidak terdapat konflik kepentingan apapun terkait studi pada naskah ini.

\section{KONTRIBUSI PENULIS}

Nurfitri Bustamam - mendesain penelitian, mengumpulkan dan menganalisis data, serta menyusun naskah publikasi.

Diana Agustini Purwaningastuti - mendesain penelitian dan mengumpulkan data.

\section{DAFTAR PUSTAKA}

1. Perhimpunan Ahli Anatomi Indonesia. Buku Standar Kurikulum Anatomi. Perhimpunan Ahli Anatomi Indonesia. 2019; pp. 5-7.

2. Mogali SR, Yeong WY, Tan HKJ, Tan GJS, Abrahams PH, Zary N, et al. Evaluation by medical students of the educational value of multi-material and multi-colored threedimensional printed models of the upper limb of anatomical education. Anat Sci Educ. 2018;11:54-64.
3. Azer SA, Azer S. 3D anatomy models and impact on learning: a review of the quality of the literature. Health Professions Education. 2016;2:80-98.

4. Peterson DC, Mlynarczyk GSA. Analysis of traditional versus three-dimensional augmented curriculum on anatomical learning outcome measures. Anat Sci Educ. 2016;9:529-36.

5. Mutalik M, Belsare S. Methods to learn human anatomy: perceptions of medical students in paraclinical and clinical phases regarding cadaver dissection and other learning methods. Int J Res Med Sci. 2016 Juli;4(7):2536-41.

6. Sheikh AH, Barry DS, Gutierrez H, Cryan JF, O'Keeffe GW. Cadaveric anatomy in the future of medical education: what is the surgeons view? Anat Sci Educ. 2016;9:203-8.

7. Custer T, Kimberly M. The utilization of the anatomage virtual dissection table in the education of imaging science students. J Tomogr Simul. 2015. https://digitalcommons. unmc. edu/ cgi/viewcontent.cgi?referer=https:// www.google.com/\&httpsredir $=1 \&$ article $=1000 \&$ context $=$ cahp_rste_articles

8. Anand MK, Singel TC. A comparative study of learning with "anatomage" virtual dissection table versus traditional dissection method in neuroanatomy. Indian J Clin Anat Physiol. 2017;4(2):177-80.

9. Kazoka D, Pilmane M. 3D dissection tools in anatomage supported interactive human anatomy teaching and learning. SHS Web of Conferences 2019;68. https://www. shs-conferences.org/articles/shsconf/ pdf/2019/09/shsconf_shw2019_02015.pdf

10. Newble D, Cannon R. A Handbook for Medical Teachers. $4^{\text {th }}$ ed. London: Kluwer Academic Publication. 2001; pp. 1-13.

11. Pandey P, Zimitat C. Medical students' learning of anatomy: memorization, understanding and visualization. Med Educ. 2007;41:7-14.

12. Boscolo-Berto R, Tortorella C, Porzionato A, Stecco C, Picardi EEE, Macchi V, et al. The additional role ofvirtual totraditional dissection 
inteaching anatomy: arandomised controlled trial. Surgical and Radiologic Anatomy. 2020. https://doi.org/10.1007/s00276-020-02551-2

13. Baratz G, Wilson-Delfosse AL, Ratnaparkhi R, Jenks BP, Singelyn BM, Carlton C, et al. Evaluating the anatomage table compared to cadaveric dissection as a learning modality for gross anatomy. Medical Science Educator. 2019. https://doi.org/10.1007/s40670-019-00719-z

14. Allen MA, Kirkpatrick N, Agosto ER. Anatomage Table 6. Journal of Electronic Resources in Medical Libraries. 2019:1-8. https://trace.tennessee.edu/ cgi/ viewcontent. cgi?article $=1031 \&$ context $=$ utk_libpub

15. Paech D, Giesel FL, Schlemmer H-P, Unterhinninghofen R, Kuner T, Doll S. Cadaverspecific CT scans visualized at the dissection table combined with virtual dissection tables improve learning performance in general gross anatomy. Eur Radiol. 2017. May;27(5):2153-60.

16. Ruiz JG, Cook DA, Levinson AJ. Computer animations in medical education: a critical review literature. Med Educ. 2009;43:838-46.

17. Wainman B, Wolak L, Pukas G, Zheng E, Norman GR.The superiority of threedimensional physical models to two-dimensional computer presentations in anatomy learning. Med Educ. 2018:52:1138-46
18. Fyfe S, Fyfe G, Dye D, Radley-Crabb H.The anatomage table: differences in student ratings between initial implementation and established use. Focus on Health Professional Education: A Multi-Professional Journal 2018;19(2). https:// fohpe.org/FoHPE/ article/view/215/131

19. Estai M, Bunt S. Best teaching practices in anatomy education: a critical review. Ann. Anatomy. 2016. http://dx.doi.org/10.1016/j. aanat.2016.02.010

20. Tenaw B. Teaching gross anatomy: anatomage table as an innovative line of attack. Int J Anat Var. 2020;13(1): 76-9.

21. Qamar K, Ahmad A, Ashar A. Comparison of learning anatomy with cadaveric dissection and plastic models by medical students. Pak Armed Forces Med J. 2004;64(2):219-24.

22. Bergman EM, Van Der Vleuten CPM, Scherpbier AJJA. Why don't they know enough about anatomy? A narrative review. Med Teach. 2011;33:403-9. 